ZOOLOGIA 31 (4): 337-342, August, 2014

http://dx.doi.org/10.1590/S1984-46702014000400005

\title{
Estimation of dry mass of caddisflies Phylloicus elektoros (Trichoptera: Calamoceratidae) in a Central Amazon stream
}

\author{
Renato T. Martins ${ }^{1,4}$, Adriano S. Melo², José F. Gonçalves Jr ${ }^{3} \&$ Neusa Hamada ${ }^{1}$
}

\author{
1 Programa de Pós-Graduação em Entomologia, Coordenação de Biodiversidade, Instituto Nacional de Pesquisas da Amazônia. \\ Avenida André Araujo 2936, 69060-000 Manaus, AM, Brazil. \\ ${ }^{2}$ Departamento de Ecologia, Instituto de Ciências Biológicas, Universidade Federal de Goiás. Caixa Postal 131, \\ 74001-970 Goiânia, GO, Brazil. \\ ${ }^{3}$ Laboratório de Limnologia, Departamento de Ecologia, Instituto de Ciências Biológicas, Universidade de Brasília. \\ 70910-900 Brasília, DF, Brazil. \\ ${ }^{4}$ Corresponding autor. E-mail: martinsrt@gmail.com
}

\begin{abstract}
Aquatic invertebrate biomass estimations are often important in ecological and biological studies. Biomass may be determined by regression models between body and case dimensions and dry mass. Using linear, exponential and power regressions we analyzed the relationship between body and case dimensions and the biomass of Phylloicus elektoros Prather, 2003. Furthermore, we used cross-validation to evaluate the predictions of our models and of the models developed for Phylloicus sp. from southeastern Brazil. We measured four body dimensions (head capsule width, interocular distance, body and pronotum length) of 152 larvae and two case dimensions (width and length) of 45 cases. Case width provided better fit with biomass than case length in all model classes. Body length provided the best biomass prediction. Biomass predictions using models proposed in the literature were $75 \%$ lower than the observed values. The power model provided the best fit between body and case dimensions with biomass. However, exponential models also provided good biomass estimates. We observed a close fit between body and case dimensions and biomass, but the predictive power of the models was low ( 40\%). The predictive power of models proposed in the literature was much worse than those built from local data and thus we do not recommend their use to predict the biomass of organisms from different regions.
\end{abstract}

KEY WORDS. Aquatic insects; allometric relationship; biomass; body dimensions; case dimensions.

Population density is used in many ecological studies as a measure of ecological importance. However, coexisting species may differ in body size and thus have different levels of ecological importance with respect to a particular ecosystem function (WOODWARD et al. 2005). For this reason, biomass determination can be very important in ecological studies. Aquatic invertebrate biomass has been used in ecological studies to determine secondary production, transference of energy in the food chain, life history and growth rate (BENKE 1996, Burgherr \& MeYer 1997). Biomass can also be used to assess the preponderance of functional groups in different portions of an environmental gradient (e.g., the River Continuum Concept, VANNote et al. 1980) and in studies that aim to detect human disturbances and leaf breakdown (MASON JR et al. 1983, LigEiro et al. 2010).

Although biomass is important to several ecological processes, it is not easy to measure (RADTKE \& Williamson 2005). Biomass can be determined directly by weighing individuals, or indirectly by determining their biovolume or the relationship between body dimensions and mass (BENKE et al. 1999). Biomass estimation based on body dimensions is faster and more accurate than biovolume and direct methods, especially in the case of small invertebrates (Burgherr \& MEYer 1997, BRAdy \& Noske 2006). Moreover, unlike biovolume and direct weighting, which require that the entire sample is dried out, samples used for biomass estimation can also be used in additional studies (e.g., molecular analyses; Towers et al. 1994).

When determining biomass directly, problems may arise as a result of the sampling method, sample handling, drying, period of collecting and method of preservation (MASON JR et al. 1983, LeUven et al. 1985, Wetzel et al. 2005). Moreover, the regression models for body dimensions and biomass are generally taxon-specific. They are also dependent on the genetic makeup of individuals and the environmental conditions of the geographical area studied, (BENKE et al. 1999), and for that reason caution should be taken when extrapolating these regressions from one place to another (BurgherR \& MEYer 1997).

Phylloicus caddisflies (Trichoptera) are important leaf shredders in Neotropical streams. Their behavior, and their role in leaf breakdown, has been subjected to several laboratory studies (Graça et al. 2001, Rincón \& Martínez 2006, MoretTi et

2014 Sociedade Brasileira de Zoologia | www.sbzoologia.org.br | www.scielo.br/zool All content of the journal, except where identified, is licensed under a Creative Commons attribution-type BY-NC. 
al. 2009, LANDeiro et al. 2010). In the Neotropical region, the biomass of species of Phylloicus has only been estimated for areas in Venezuela (CRESSA 1999a) and Southeastern Brazil (BECKER et al. 2009).

In the Amazon region, there have been no studies estimating the biomass of Phylloicus from the dimensions of the body or case. To fill this gap, we analyze this relationship for Phylloicus elektoros Prather, 2003, collected from a stream in Central Amazonia using linear, exponential and power regressions. The predictive power of the fitted models was assessed by cross-validation. We also evaluate whether the relationship between body dimensions and biomass are specific to the studied population. To this end, we tested the predictive power of regression models published for Phylloicus sp. from another region of Brazil by using them to estimate the biomass of our samples.

\section{MATERIAL AND METHODS}

Larvae of $P$. elektoros with different body sizes were collected in September 2012 (dry season) from the Barro Branco stream, at the Ducke Reserve $\left(02^{\circ} 55^{\prime}\right.$ and $03^{\circ} 01^{\prime} \mathrm{S}, 5^{\circ} 53^{\prime}$ and $59^{\circ} 59^{\prime} \mathrm{W}$ ), ca $50 \mathrm{~km}$ from the city of Manaus, AM, Central Amazonia, Brazil. This reserve has about 10,000 ha of preserved upland ("terra firme") forest (Ribeiro et al. 1999). The Barro Branco stream has dense riparian vegetation and closed canopy, acidic water $(\mathrm{pH}=4.63 \pm 0.08)$, high dissolved oxygen $(6.62 \pm$ $0.06 \mathrm{mg} / \mathrm{l})$, low electrical conductivity $(10.71 \pm 0.41 \mu \mathrm{S} / \mathrm{cm})$ and average temperatures of $24.52 \pm 0.52^{\circ} \mathrm{C}$. The abiotic variables were measured on the day larvae were collected.

A total of 152 larvae with cases were located (principally in pool areas), collected manually in a single day and transported to the laboratory. There, individuals were removed from their cases, individualized in containers, and preserved in $80 \%$ alcohol in a $20^{\circ} \mathrm{C}$ freezer for two months before analyses. The larval cases were also preserved in $80 \%$ alcohol at $-20^{\circ} \mathrm{C}$ in the same vials containing their larvae. We opted for alcohol preservation because it takes a long time to measure all individuals and because the material was also being used for another study. We used four body dimensions as predictors of biomass: body length, head capsule width, intraocular distance and pronotum length. Body length was measured as the distance between the anterior portion of the head and the posterior portion of the abdomen. Head capsule width was the distance across the widest section of the head. Interocular distance was measured as the minimum distance between the eyes. Pronotum length was measured along the mid-dorsal ecdysial line. These body dimension measurements followed BECKER (2005) and BECKER et al. (2009). We also used case length (ventral portion) and width (widest part at the opening) to estimate biomass because individuals of Phylloicus are usually collected with their cases (CRESSA 1999a). The dimensions of the cases and the bodies of the larvae were measured using Leica M165 stereo-microscope im- ages (accuracy $=0.001 \mathrm{~mm}$ ). Later, the larvae were dried at $60^{\circ} \mathrm{C}$ for 48 hours (Meyer 1989), cooled in desiccators for 24 hours (CRESSA 1999a, b) and individually weighed (accuracy = $0.01 \mathrm{mg}$ ). In a few cases, certain body dimensions were not recorded because the larvae were injured or because they were too curved (which would cause imprecise measurements). Case dimensions were obtained for 45 larvae.

In order to determine the best fit between dimensions (body and case) and P. elektoros biomass we used three regression models: linear $\left(y=a+b{ }^{*} x\right)$, exponential $\left(y=a * e^{b x}\right.$; in linear form: $\left.\ln \mathrm{y}=\ln \mathrm{a}+\mathrm{b}^{*} \mathrm{x}\right)$ and power $\left(\mathrm{y}=\mathrm{a}{ }^{*} \mathrm{x}^{\mathrm{b}}\right.$; in linear form: $\left.\ln \mathrm{y}=\ln \mathrm{a}+\mathrm{b}{ }^{*} \ln \mathrm{x}\right)$, where $\mathrm{y}$ is weight $(\mathrm{mg})$ and $\mathrm{x}$ is body or case dimensions $(\mathrm{mm})$. To express the exponential and power models in linear form the data were logarithmic transformed (ln). We evaluated the fit of regression models based on coefficients of determination $\left(\mathrm{R}^{2}\right)$ (ZAR 2010).

Coefficients of determination estimated from a sample are usually higher than those produced using the same regression but applied to different sampled data. Accordingly, a proper assessment of the predictive power of models should be done using cross-validation, that is, how well results predicted by a model compare to observed data that were not used to estimate the model. We did this by 1 ) randomly splitting our dataset in half $(1: 1)$; 2$)$ using one of the subsets to create the model (training set) using power and exponential regressions and 3) using the other subset to assess the predictive performance of the models (test set). To evaluate whether models developed for Phylloicus in other regions produce good estimates of the local biomass of $P$. elektoros, we used the power and exponential models proposed by BECKER et al. (2009), which are based on a population of Phylloicus sp. in southeastern Brazil, and the test dataset (obtained in step 3 above). We assessed the reliability of the two estimates (our cross-validation and that using the model of BECKER et al. 2009) by comparing the results with the biomass determined directly from larvae. These comparisons were carried out using a one-way blocked Analysis of Variance (ANOVA). Larvae in the test dataset were blocks in the ANOVA. Distinct random splits of the entire dataset may result in distinct results. Accordingly, we repeated the crossvalidation with the prediction using the formulae of BECKER et al. (2009) and the ANOVA 100 times and obtained averages of the results.

Two voucher specimens of $P$. elektoros were deposited in Entomological collection of Instituto Nacional de Pesquisas da Amazônia (INPA), Manaus, Brazil.

\section{RESULTS}

Body length ranged from $5.17 \mathrm{~mm}$ to $18.79 \mathrm{~mm}$ (Table I). Dry mass was highly variable, with values that ranged from 0.80 to $125.70 \mathrm{mg}$ (Table I). Coefficients of variation were similar for all body dimensions ( 25\%). Case dimensions showed higher coefficients of variation than body dimensions (Table I). 
Table I. Range, mean, standard deviation (SD), coefficient of variation $\left(\mathrm{CV}=(\mathrm{SD} / \mathrm{mean})^{\star} 100\right.$, in $\left.\%\right)$ and number of observations (N) for body mass and body and case dimensions of Phylloicus elektoros larvae from a Central Amazonian stream.

\begin{tabular}{lccccc}
\hline & Range & Mean & SD & CV & $\mathrm{N}$ \\
\hline Body dimensions & & & & & \\
$\quad$ Body length (mm) & $5.17-18.79$ & 12.62 & 3.22 & 25.52 & 150 \\
Head capsule width (mm) & $0.43-1.28$ & 0.96 & 0.21 & 21.64 & 150 \\
Interocular distance (mm) & $0.19-0.80$ & 0.58 & 0.14 & 23.84 & 150 \\
$\quad$ Pronotum length (mm) & $0.38-1.29$ & 0.89 & 0.21 & 24.12 & 150 \\
Case dimensions & & & & & \\
$\quad$ Case length (mm) & $7.98-36.38$ & 19.67 & 6.84 & 34.74 & 45 \\
Case width (mm) & $2.79-9.52$ & 6.17 & 1.86 & 30.10 & 45 \\
Body mass & & & & & \\
Dry mass (mg) & $0.80-125.70$ & 26.69 & 23.17 & 86.80 & 152 \\
\hline
\end{tabular}

All regression models used to estimate the biomass of $P$. elektoros were significant ( $\mathrm{p}<0.001$, Table II). The best fit between body mass and case or larval dimensions was provided by the power models, followed by the exponential and the linear models. For the three model classes, case width fit biomass better than case length. Body length yielded the best biomass predictions of all model classes (Table II).

We recorded significant differences in the biomass predicted using the models proposed by BECKER et al. (2009), our cross-validated models, and the observed biomass (Table III). The predicted biomass using power and exponential models in our cross-validation study was approximately $20 \%$ higher than the observed biomass (Table III). On the other hand, the predicted biomass using the models proposed by BECKER et al. (2009) was 75\% lower than the observed values.

As expected, the coefficients of determination using predicted values (i.e., cross-validation) were lower (Table III) than those estimated using the same data set (Table II). Cross-validated coefficients of determination for body dimensions were similar for power and exponential models. However, power models using case dimensions performed much better than exponential models. Biomass predictions using models for Phylloicus sp. developed by BECKer et al. (2009) were not only strongly negatively biased but were also not better than the predictions of a model composed of a single constant (the mean; in all cases $\mathrm{R}^{2}=0$ ).

\section{DISCUSSION}

The best model for body dimensions was the one for body length, which explained up to $68 \%$ of the biomass variation. Previous studies have shown that body length provides good estimates of the biomass of several aquatic insect larvae (SMOCK 1980, Benke et al. 1999, Genkai-Kato \& Miyasaka 2007). Body length was also the best predictor of biomass for a population
Table II. Linear, exponential and power models for the relationship between body mass $(\mathrm{mg})$ and body and case dimensions $(\mathrm{mm})$ of Phylloicus elektoros larvae from a Central Amazonian stream. (DM) Dry mass, (BL) body length, (HW) head capsule width, (ID) interocular distance, $(\mathrm{PL})$ pronotum length, $(\mathrm{CL})$ case length, $(\mathrm{CW})$ case width. For all models $p<0.001$.

\begin{tabular}{|c|c|c|c|c|c|}
\hline Function & Models & a & $\mathrm{b}$ & $\mathrm{r}^{2}$ & $\mathrm{n}$ \\
\hline \multirow[t]{6}{*}{ Linear } & $\mathrm{DM} \sim \mathrm{BL}$ & -34.383 & 4.849 & 0.450 & 150 \\
\hline & $\mathrm{DM} \mathrm{HW}$ & -41.892 & 71.108 & 0.413 & 150 \\
\hline & $D M \sim I D$ & -35.928 & 108.599 & 0.417 & 150 \\
\hline & $\mathrm{DM} \sim \mathrm{PL}$ & -31.551 & 65.603 & 0.363 & 150 \\
\hline & $\mathrm{DM} \sim \mathrm{CL}$ & -28.464 & 2.908 & 0.620 & 45 \\
\hline & $\mathrm{DM} \sim \mathrm{CW}$ & -37.358 & 10.704 & 0.621 & 45 \\
\hline \multirow[t]{6}{*}{ Exponential } & $\ln (\mathrm{DM}) \sim \mathrm{BL}$ & -0.408 & 0.258 & 0.662 & 150 \\
\hline & $\ln (\mathrm{DM}) \sim \mathrm{HW}$ & -0.850 & 3.848 & 0.637 & 150 \\
\hline & $\ln (\mathrm{DM}) \sim \mathrm{ID}$ & -0.562 & 5.938 & 0.657 & 150 \\
\hline & $\ln (\mathrm{DM}) \sim \mathrm{PL}$ & -0.348 & 3.600 & 0.569 & 150 \\
\hline & $\ln (\mathrm{DM}) \sim \mathrm{CL}$ & 0.442 & 0.123 & 0.574 & 45 \\
\hline & $\ln (\mathrm{DM}) \sim \mathrm{CW}$ & -0.230 & 0.501 & 0.703 & 45 \\
\hline \multirow[t]{6}{*}{ Power } & $\ln (\mathrm{DM}) \sim \ln (\mathrm{BL})$ & -4.558 & 2.967 & 0.676 & 150 \\
\hline & $\ln (\mathrm{DM}) \sim \ln (\mathrm{HW})$ & 3.071 & 3.316 & 0.645 & 150 \\
\hline & $\ln (\mathrm{DM}) \sim \ln (\mathrm{ID})$ & 4.555 & 2.893 & 0.657 & 150 \\
\hline & $\ln (\mathrm{DM}) \sim \ln (\mathrm{PL})$ & 3.284 & 2.855 & 0.579 & 150 \\
\hline & $\ln (\mathrm{DM}) \sim \ln (\mathrm{CL})$ & -4.262 & 2.440 & 0.605 & 45 \\
\hline & $\ln (\mathrm{DM}) \sim \ln (\mathrm{CW})$ & -2.543 & 3.047 & 0.738 & 45 \\
\hline
\end{tabular}

of Phylloicus sp. in Southeast Brazil (BeскеR et al. 2009). In caddisflies the abdomen is usually less sclerotized than the pronotum or the head capsule, and grows continuously through the different instars, allowing for best fit with biomass (BENKE et al. 1999).

Intraocular distance and head capsule width also provided high coefficients of determination. These body dimensions were highlighted by CRessa (1999a) and BeCKer et al. (2009) as good predictors of biomass for Phylloicus sp. Sclerotized structures are considered more reliable than body length to estimate the biomass of preserved organisms because they are less subject to breakage and deformation (JoHnston \& CunJAK 1999). However, our fitted regressions using sclerotized structures provided lower fit than did body length. According to Nolte (1990), the use of $70 \%$ ethanol to preserve Chironomidae has little effect on larval shape. In our study, we did not observe great alterations in the shape of the body of P. elektoros. Moreover, all specimens were individualized before alcohol preservation. This procedure is supposed to reduce specimen breakage, which could impact biomass determination (RADTKE \& Williamson 2005).

Preservation of invertebrates in alcohol is often necessary due to the large volume of material collected and the time 
Table III. Predictive performance of cross-validation models and the models developed by BECKER et al. (2009) to estimate biomass of Phylloicus elektoros from a Central Amazonian stream. Difference indicates percentage of difference between predicted and observed data. Positive differences indicate that the predicted values were higher than the observed ones. $F$ and $p$ refers to tests between observed and predicted values. For cases in which models by BECKER et al. (2009) are available, a one-way blocked analysis of variance was performed. For the remaining cases a paired t-test was performed. In both analyses, larvae were considered in blocks (or pairs). Values refer to averages obtained from predictions and tests repeated 100 times (see Methods). (DM) Dry mass, (BL) body length, (HW) head capsule width, (ID) interocular distance, $(\mathrm{PL})$ pronotum length, $(\mathrm{CL})$ case length, $(\mathrm{CW})$ case width.

\begin{tabular}{|c|c|c|c|c|c|c|c|c|}
\hline \multirow{2}{*}{ Model } & \multirow{2}{*}{ Body and case dimensions } & \multicolumn{2}{|c|}{ Difference (\%) } & \multicolumn{2}{|r|}{$r^{2}$} & \multicolumn{3}{|c|}{ Analysis of variance } \\
\hline & & Test data & BECKER et al. (2009) & Test data & BECKER et al. (2009) & $\mathrm{F}$ & d.f. & $\mathrm{p}$ \\
\hline \multirow[t]{6}{*}{ Exponential } & $\mathrm{BL}$ & 19.29 & -75.54 & 0.38 & 0.00 & 66.31 & 2,148 & $<0.001$ \\
\hline & HW & 23.20 & -75.01 & 0.38 & 0.00 & 71.22 & 2,148 & $<0.001$ \\
\hline & ID & 21.50 & -87.57 & 0.39 & 0.00 & 82.49 & 2,148 & $<0.001$ \\
\hline & PL & 26.74 & - & 0.31 & - & 5.44 & 1,740 & 0.136 \\
\hline & $\mathrm{CL}$ & 43.08 & - & 0.18 & - & 2.71 & 1,220 & 0.348 \\
\hline & CW & 26.54 & - & 0.00 & - & 3.72 & 1,220 & 0.289 \\
\hline \multirow[t]{6}{*}{ Power } & $\mathrm{BL}$ & 17.10 & -77.08 & 0.42 & 0.00 & 71.05 & 2,148 & $<0.001$ \\
\hline & HW & 22.16 & -77.16 & 0.38 & 0.00 & 74.60 & 2,148 & $<0.001$ \\
\hline & ID & 20.87 & -90.85 & 0.37 & 0.00 & 87.10 & 2,148 & $<0.001$ \\
\hline & PL & 28.89 & - & 0.31 & - & 5.69 & 1,740 & 0.155 \\
\hline & $C L$ & 35.27 & - & 0.51 & - & 3.35 & 1,220 & 0.304 \\
\hline & $\mathrm{CW}$ & 17.50 & - & 0.45 & - & 3.26 & 1,220 & 0.344 \\
\hline
\end{tabular}

needed to process samples (Leuven et al. 1985, Nolte 1990). However, insect preservation in alcohol could result in more than 50\% weight loss (HowmiLler 1972). This generally results from the dissolution of large amounts of lipids that are present in the larval body (WeTzel et al. 2005), but can be prevented by storing the insect in low temperatures $\left(-20^{\circ} \mathrm{C}\right)$. According to LeUven et al. (1985), storage of the Gastropod Radix peregra (Müller, 1774) in $70 \%$ alcohol at $-15^{\circ} \mathrm{C}$ during four months resulted in less than 5\% mass loss. Additionally, Ме́тнот et al. (2012) assessed the relative importance of storage period, preservation method, continent, investigator, and taxonomic level to determine invertebrate biomass, and observed that the effects of preservation were small and represented less than 3\% of the total variation in the estimated biomass.

We observed that the dimensions (length and width) of the case provided good biomass estimates for P. elektoros. Other studies have used case dimensions efficiently to predict the biomass of other Trichoptera species (Grafius \& ANDERson 1980, Cressa 1999a, Campos \& González 2009). According to Cressa (1999a), the relationship between case dimensions and biomass are predictable because changes in case size closely follow individual growth. The high fit of case dimension models provides a way to measure the same individual on several occasions and thus allows longitudinal studies to be performed (CRESSA 1999a).

Power models provided the best fits for P. elektoros biomass and body and case dimensions, although exponential models performed only slightly more poorly than power models.
According to Wenzel et al. (1990), differences in biomass predicted using different regression models tend to be low, and to decrease when more specimens are used. The power model is the most frequently used in the literature to estimate invertebrate biomass (e.g., SMOck 1980, Towers et al. 1994, Burgherr \& Meyer 1997). However, we emphasize that the exponential model may provide satisfactory results for the relationship between body mass and body dimensions (GonzÁLEz et al. 2002, BECKER et al. 2009).

According to Cooll et al. (1987), regression models do not provide good fit and show high predictive power in all cases. In our study, the coefficients of determination of models using cross-validation (test data) were very low compared to models estimated from sample data. This indicates that the difference between predicted and observed biomass may be important, and thus that biomass predictions may not be very reliable. Although we observed a good fit between body and case dimensions and biomass for P. elektoros, the predictive power of these models was low.

A perfect cubic relationship between body mass and body dimensions is obtained when the slope value (b) of the power model is 3 (Stoffels et al. 2003). According to Cressa (1999a), the relationships for most tropical aquatic insects show slopes lower than 3, usually between 1.34 in Nectopsyche sp. and 2.88 in Leptonema sp. The only exception seems to be a species of Phylloicus studied by Cressa (1999a), who found a slope of 4.50 for populations in Venezuela, and BECKER et al. (2009), who reported coefficient values higher than 3 for Phylloicus sp. in 
Southeast Brazil. In our study, slope values were high but were usually lower than 3 , except for head capsule width $(b=3.32)$. Slope values close to 3 indicate that biomass is more influenced by body volume than by body surface area (ENGELMANN 1961, Benke et al. 1999). Thus changes in the biomass of $P$. elektoros are more pronounced than changes in body and case dimensions (Cressa, 1999a).

According to Wenzel et al. (1990) differences between observed and estimated biomass produced by a good model should be lower than $20 \%$. Using the exponential and power models obtained in our study (test data), the difference between estimated and observed biomasses was slightly higher than $20 \%$. On the other hand, literature models (BECKER et al. 2009) for Phylloicus sp. from Southeastern Brazil underestimated biomass by $75 \%$ in relation to the observed data. This agrees with previous studies in which relationships between mass and body dimensions of insects collected in a given area usually are not efficient to make predictions based on other regions (Johnston \& Cunjak 1999, Miserendino 2001). This may be the result of possible differences in species identity, environmental variables, food availability or population genetics (BASSET \& Glazier 1995, Burgherr \& Meyer 1997, Benke et al. 1999, BAUMGÄRTNER \& RothHAUPT 2003).

We conclude that the power model provided the best fit between body and case dimensions and biomass. However, the exponential model also provided good biomass estimates. Our cross-validation study showed that our models do not predict the biomass of P. elektoros well. Additionally, we found that the predictive ability of models built for other regions performed even worse. Accordingly, literature models should not be used for regions other than the ones on which they were based. We suggest that, in order to attain more reliable perditions, the size-mass relationship should be based on the target population.

\section{ACKNOWLEDGMENTS}

We thank Ana M.O. Pes for help in P. elektoros identification, Philip M. Fearnside for the English review and the Conselho Nacional de Desenvolvimento Científico e Tecnológico (CNPq) for the authors' scholarships. We are also thankful to two anonymous reviewers who provided useful comments on the manuscript. RTM received a doctoral scholarship (Proc. 143624/2009-1), ASM and NH received research grants (Procs 558187/2009-9 and 504223/2010-0, respectively) and research fellowships (Procs 307479/2011-0 and 306328/ 2010-0). RTM received Programa de apoio à fixação de Doutores no Amazonas - FIXAM/AM fellowship. CT-Amazônia/CNPq (Proc. 575875/2008-9), Pronex/CNPq/Fapeam - Aquatic insects, INCT/ADAPTA - Amazon, MCTI/CNPq/CT-AGRO/CT-SAÚDE/ CT-HIDRO - Mudanças Climáticas (Proc. 403949/2013-0) and Pró-equipamentos Institucional/CAPES projects supported the field sampling and stereo microscope acquisition.

\section{LITERATURE CITED}

Basset, A. \& D.S. Glazier. 1995. Resource limitation and intraspecific patterns of weight $\mathrm{x}$ length variation among spring detritivores. Hydrobiologia 316 (2): 127-137. doi: 10.1007/BF00016894

Baumgärtner, D. \& K.O. Rothhaupt. 2003. Predictive length-dry mass regressions for freshwater invertebrates in a pre-alpine lake littoral. International Review of Hydrobiology 88 (5): 453-463. doi: 10.1002/iroh.200310632

Becker, G. 2005. Life cycle of Agapetus fuscipes (Trichoptera, Glossosomatidae) in a first-order upland stream in central Germany. Limnologica 35 (1-2): 52-60. doi: 10.1016/ j.limno.2005.01.003

Becker, B.; M.S. Moretti \& M. Callisto. 2009. Length-dry mass relationships for a typical shredder in Brazilian streams (Trichoptera: Calamoceratidae). Aquatic Insects 31 (3): 227234. doi: $10.1080 / 01650420902787549$

BENKE, A. 1996. Secondary production of macroinvertebrates, p. 557-578. In: F.R. Hauer \& G.A. LAmberTI (Eds). Methods in Stream Ecology. New York, Academic Press, 896p.

Benke, A.; A. Huryn; L. Smock \& J. Wallace. 1999. Length-mass relationships for freshwater macroinvertebrates in North America with particular reference to the southeastern United States. Journal of the North American Benthological Society 18 (3): 308-343. doi: 10.2307/1468447

Brady, C.J. \& R.A. Noske. 2006. Generalised regressions provide good estimates of insect and spider biomass in the monsoonal tropics of Australia. Australian Journal of Entomology 45 (3): 187-191. doi: 10.1111/j.1440-6055.2006.00533.x

Burgherr, P. \& E.I. Meyer. 1997. Regression analysis of linear body dimensions vs. dry mass in stream macroinvertebrates. Archiv für Hydrobiologie 139 (1): 101-112.

Campos, J. \& J.M. González. 2009. Sericostoma vittatum (Trichoptera) larvae are able to use pine litter as an energy source. International Review of Hydrobiology 94 (4): 472 483. doi: 10.1002/iroh.200811155

Cooll, B.; S.W. Russell \& D.L. Rados. 1987. Cross-Validation for Prediction. Journal of Marketing Research 24 (3): 271-279.

Cressa, C. 1999a. Dry mass estimates of some tropical aquatic insects. Revista de Biología Tropical 47 (1-2): 133-141.

CREssa, C. 1999b. Dry mass estimation of tropical aquatic insects using different short-term preservation methods. Revista de Biología Tropical 47 (1-2): 143-149.

ENGELMANN, M.D. 1961. The role of soil arthropods in the energetics of an old field community. Ecological Monographs 31(3): 221-238. doi: $10.2307 / 1948553$

GenKai-Kato, M. \& H. MiyasaKa. 2007. Length-weight relationships of four predatory stonefly species in Japan. Limnology 8 (2): 171-174. doi: 10.1007/s10201-007-0210-8

GonzÁlfz, J.M.; A. Basaguren \& J. Pozo. 2002. Size-mass relationships of stream invertebrates in a northern Spain stream. Hydrobiologia 489 (1-3): 131-137. doi: 10.1023/A:1023220501921 
Graça, M.A.S.; C. Cressa; M.O. Gessner; M.J. Feio; K.A. Callies \& C. BARRIos. 2001. Food quality, feeding preferences, survival and growth of shredders from temperate and tropical streams. Freshwater Biology 46 (7): 947-957. doi: 10.1046/ j.1365-2427.2001.00729.x

Grafius, E. \& N.H. Anderson. 1980. Population dynamics and role of two species of Lepidostoma (Trichoptera: Lepidostomatidae) in an Oregon coniferous forest stream. Ecology 61 (4): 808816. doi: $10.2307 / 1936751$

HowmiLLER, R.P. 1972. Effects of preservatives on weights of some common macrobenthic invertebrates. Transactions of the American Fisheries Society 101 (4): 743-746. doi: 10.1577/ 1548-8659(1972)101<743:EOPOWO>2.0.CO;2

Johnston, T. \& R. Cunjak. 1999. Dry mass-length relationships for benthic insects: a review with new data from Catamaran Brook, New Brunswick, Canada. Freshwater Biology 41 (4): 653-674. doi: 10.1046/j.1365-2427.1999.00400.x

Landeiro V.L.; N. Hamada; B.S. Godoy \& A.S. Melo. 2010. Effects of litter patch area on macroinvertebrate assemblage structure and leaf breakdown in Central Amazonian streams. Hydrobiologia 649 (1): 355-363. doi: 10.1007/s10750-010-0278-8

Leuven, R.S.E.W.; T.C.M. Brock \& H.A.M. Van Druten. 1985. Effects of preservation on dry- and ash-free dry weight biomass of some common aquatic macro-invertebrates. Hydrobiologia 127 (2): 151-159. doi: 10.1007/BF00004193

Ligeiro, R.; M.S. Moretti; J.F. Gonçalves Jr \& M. Callisto. 2010. What is more important for invertebrate colonization in a stream with low quality litter inputs: exposure time or leaf species? Hydrobiologia 654 (1): 125-136. doi: 10.1007/ s10750-010-0375-8

Mason Jr, W.T.; P.A. Lewis \& C.I. Weber. 1983. An evaluation of benthic macroinvertebrate biomass methodology. Part 1 . Laboratory analytical methods. Environmental Monitoring and Assessment 3 (1): 29-44. doi: 10.1007/BF00394030

Méthot, G.; C. Hudon; P. Gagnon; B. Pinel-Alloul; A. Armellin \& A.M.T. PoIRIER. 2012. Macroinvertebrate size-mass relationships: how specific should they be? Freshwater Science 31 (3): 750764. doi: 10.1899/11-120.1

Meyer, E. 1989. The relationship between body length parameters and dry mass in running water invertebrates. Archiv für Hydrobiologie 117 (2): 191-203.

Miserendino, M.L. 2001. Length-mass relationships for macroinvertebrates in freshwater environments of Patagonia (Argentina). Ecología Austral 11 (1): 3-8.

Moretti, M.S.; R.D. Loyola; B. Becker \& M. Callisto. 2009. Leaf abundance and phenolic concentrations codetermine the selection of case-building materials by Phylloicus sp. (Trichoptera, Calamoceratidae). Hydrobiologia 630 (1): 199-206. doi: 10.1007/s10750-009-9792-y

Nolte, U. 1990. Chironomid biomass determination from larval shape. Freshwater Biology 24 (3): 443-451. doi: 10.1111/ j.1365-2427.1990.tb00723.x
RadtKe, M.G. \& G.B. Williamson. 2005. Volume and linear measurements as predictors of dung beetle (Coleoptera: Scarabaeidae) biomass. Annals of the Entomological Society of America 98 (4): 548-551. doi: 10.1603/00138746(2005)098[0548:VALMAP]2.0.CO;2

Ribeiro, J.E.L.S.; M.J.G. Hopkins; A. Vicentini; C.A. Sothers; M.A.S. Costa; J.M. Brito; M.A.D. Souza; L.H.P. Martins; L.G. Lohmann; P.A.C.L. Assunção; E.C. Pereira; C.F. Silva; M.R. Mesquita. \& L.C. Procópio. 1999. Flora da Reserva Ducke: Guia de identificação das plantas vasculares de uma floresta de terra firme na Amazônia Central. Manaus, INPA, 816p.

RinCón, J. \& I. MARTÝNEZ. 2006. Food quality and feeding preferences of Phylloicus sp. (Trichoptera: Calamoceratidae). Journal of the North American Benthological Society 25 (1): 209-215. doi: 10.1899/0887-3593(2006)25[209:FQAFPO]2.0.CO;2

Sмоск, L.A. 1980. Relationships between body size and biomass of aquatic insects. Freshwater Biology 10 (4): 375-383. doi: 10.1111/j.1365-2427.1980.tb01211.x

Stoffels, R.J.; S. Karbe \& R.A. Paterson. 2003. Length mass models for some common New Zealand littoral benthic macroinvertebrates, with a note on within taxon variability in parameter values among published models, New Zealand. Journal of Marine and Freshwater Research 37 (2): 449460. doi: 10.1080/00288330.2003.9517179

Towers, D.J.; I.M. Henderson \& C.J. Veltman. 1994. Predicting dry weight of New Zealand aquatic macroinvertebrates from linear dimensions. New Zealand Journal of Marine and Freshwater Research 28 (2): 159-166. doi: 10.1080/ 00288330.1994.9516604

Vannote, R.L.; G.W. Minshall; K.W. Cummins; J.R. Sedell \& C.E. Cushing. 1980. The river continuum concept. Canadian Journal of Fisheries and Aquatic Sciences 37 (1): 130-137. doi: 10.1139/f80-017

Wenzel, F.; E. Meyer \& J. Schwoerbel. 1990. Morphometry and biomass determination of dominant mayfly larvae (Ephemeroptera) in running waters. Archiv für Hydrobiologie 118 (1): 31-46.

WeTZeL, M.A.; H. Leuchs \& J.H.E. Koop. 2005. Preservation effects on wet weight, dry weight, and ash-free dry weight biomass estimates of four common estuarine macro-invertebrates: no difference between ethanol and formalin. Helgoland Marine Research 59 (3): 206-213. doi: 10.1007/s10152-005-0220-z

Woodward, G.; B. Ebenman; M. Emmerson; J.M. Montoya; J.M. Olesen; A. Valido \& P.H. Warren. 2005. Body size in ecological networks. Trends in Ecology and Evolution 20 (7): 402409. doi: 10.1016/j.tree.2005.04.005

ZAR, J.H. 2010. Biostatistical Analysis. Pearson Education, New Jersey, 944p.

Submitted: 05.VII.2013; Accepted: 24.III.2014. Editorial responsibility: Mauricio O. Moura 